\title{
An observation of autosomal recessive hyper-lgE syndrome: a rare case report
}

\author{
Autosomalny recesywny zespół hiper-lgE - opis rzadkiego przypadku
}

Tasleem Arif, Mohammad Adil, Syed Suhail Amin, Konchok Dorjay

Jawaharlal Nehru Medical College (JNMC), Aligarh Muslim University (AMU), Aligarh, India

Dermatol Rev/Przegl Dermatol 2017, 104, 676-679

DOI: https://doi.org/l0.51|4/dr.2017.71840

Hyper-IgE syndrome (HIES), also referred to as Job's syndrome, is a rare immunodeficiency disorder characterized by eczema, recurrent infections and elevated IgE [1]. It is usually inherited in an autosomal dominant pattern, but a distinct subset with autosomal recessive inheritance has been observed.

We present a rare case of autosomal recessive HIES associated with pigmentation of oral mucosa and flexures, a feature never described in the literature to the best of our knowledge.

A two and a half year old female child presented to us with crusting over the face and flexures. The antenatal and birth history was uneventful. At 1 month of age, she developed red, oozing lesions over the face that healed with pigmentation. Such lesions occurred several times and subsided after unknown topical medications. The patient developed progressive darkening of oral mucosa and skin flexures from the age of 1 year. There was a history of recurrent skin infections, loose stools, ear discharge, breathing difficulty, fever and cough. The patient had developed varicella at the age of 6 months. She was born of a first degree consanguineous marriage. The patient had three sisters and one brother. The eldest sister and brother had a history of similar disease and died at the age of 3 years due to some 'febrile illness of the brain', according to the parents; the records were not available. Two siblings were normal.

On examination, the patient had a below average weight-for-age $(76.9 \%)$ and normal height-for-age $(87.7 \%)$. Lesions with yellow brown crusts and slight scaling were present over the forehead, neck, retroauricular creases, axillae and groin (figs. 1, 2). Crusts were particularly prominent near the lips (fig. 3). There was pigmentation of the bilateral axillae and groin (figs. 4, 5). Oral and buccal mucosae revealed
Zespół hiper-IgE (HIES), zwany także zespołem Hioba, jest rzadkim zespołem niedoboru odporności, który objawia się obecnością zmian wypryskowych, nawracającymi zakażeniami i podwyższonym stężeniem przeciwciał w klasie IgE [1]. Zazwyczaj jest dziedziczony w sposób autosomalny dominujący, jednak u części chorych obserwuje się autosomalny recesywny typ dziedziczenia.

Przedstawiamy rzadki przypadek HIES dziedziczonego w sposób autosomalny recesywny z obecnością przebarwień w obrębie błony śluzowej jamy ustnej oraz na powierzchniach zgięciowych. Według naszej wiedzy współwystępowanie tego objawu nie było dotąd opisane w piśmiennictwie.

Do naszego ośrodka skierowano 2,5-letnią dziewczynkę ze strupami pokrywającymi twarz oraz powierzchnie zgięciowe. Wywiad prenatalny i okołoporodowy był nieobciążony. W pierwszym miesiącu życia na twarzy dziewczynki wystąpiły zmiany rumieniowe z sączeniem, które w procesie gojenia pozostawiały przebarwienia. Pojawiały się one kilkakrotnie i ustępowały po lekach miejscowych (brak dokładnych danych z wywiadu). Od pierwszego roku życia u dziewczynki zaczęły rozwijać się postępujące przebarwienia w obrębie błony śluzowej jamy ustnej oraz na skórze gładkiej powierzchni zgięciowych. W wywiadzie stwierdzono nawracające zakażenia skóry, luźne stolce, wydzielinę z ucha, trudności z oddychaniem, gorączkę i kaszel. W wieku 6 miesięcy dziecko przebyło ospę wietrzną. Dziewczynka urodziła się w związku małżeńskim osób spokrewnionych w pierwszym stopniu. Miała trzy siostry i jednego brata. Podobna choroba wystąpiła u najstarszej siostry oraz u brata. Dzieci zmarły w wieku 3 lat - według rodziców z powodu „zapalenia mózgu”. Dokumentacja medyczna nie była dostępna. Pozostała dwójka rodzeństwa była zdrowa. 


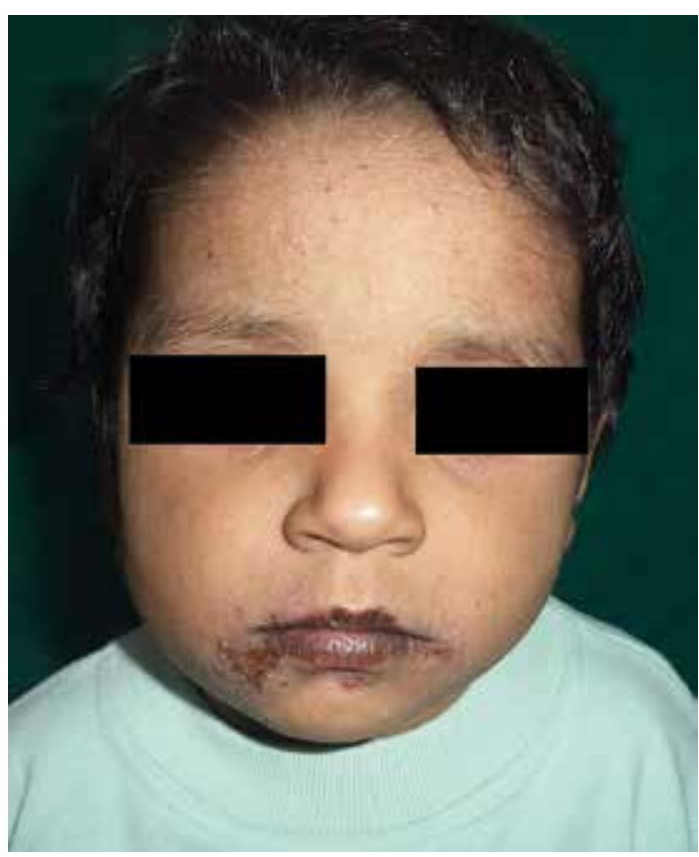

Figure I. Crusted lesions over the forehead and lips. Also visible is the pigmentation over lips

Rycina I. Strupy umiejscowione na czole i wokół ust. Widoczne także przebarwienia czerwieni wargowej

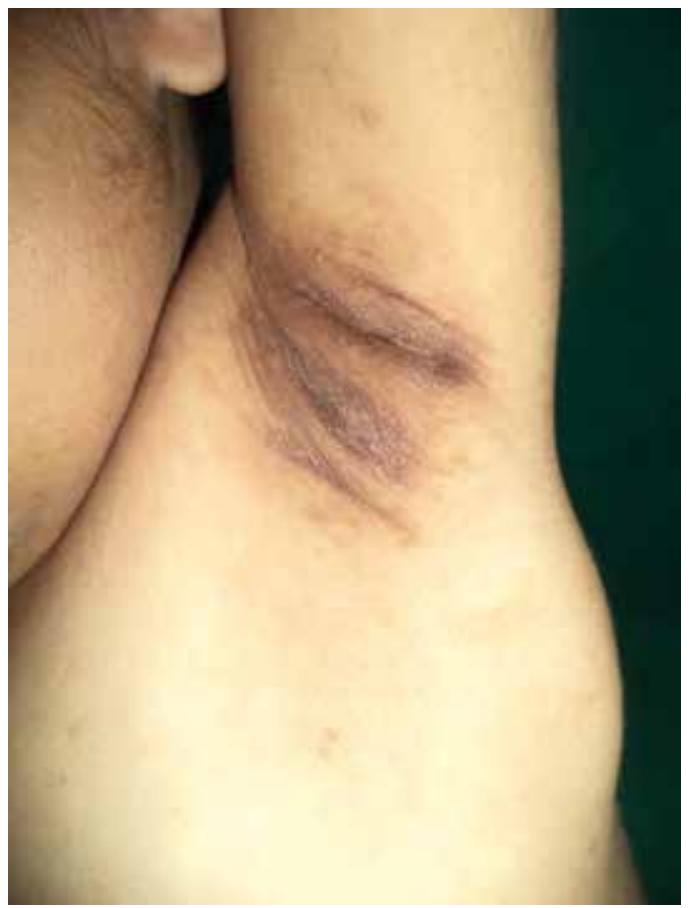

Figure 4. Eczematous lesions with pigmentation over left axillary region

Rycina 4. Zmiany wypryskowe z przebarwieniami w obrębie lewego dołu pachowego

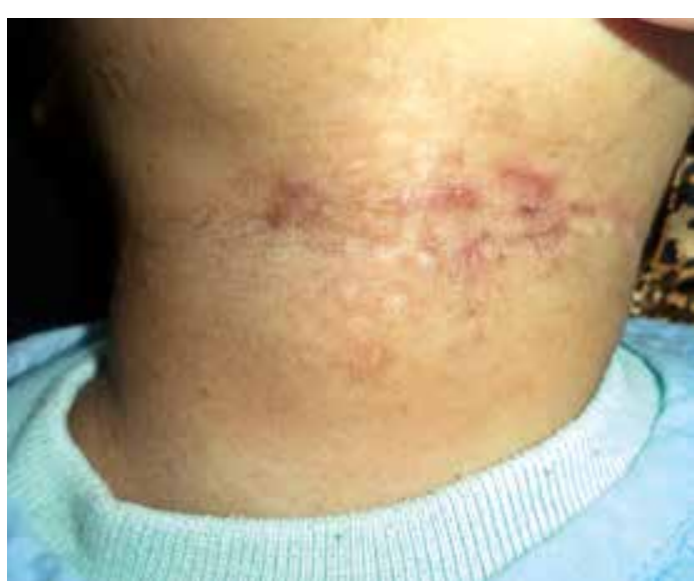

Figure 2. Eczematous lesions over neck

Rycina 2. Zmiany wypryskowe obejmujq̨ce szyję

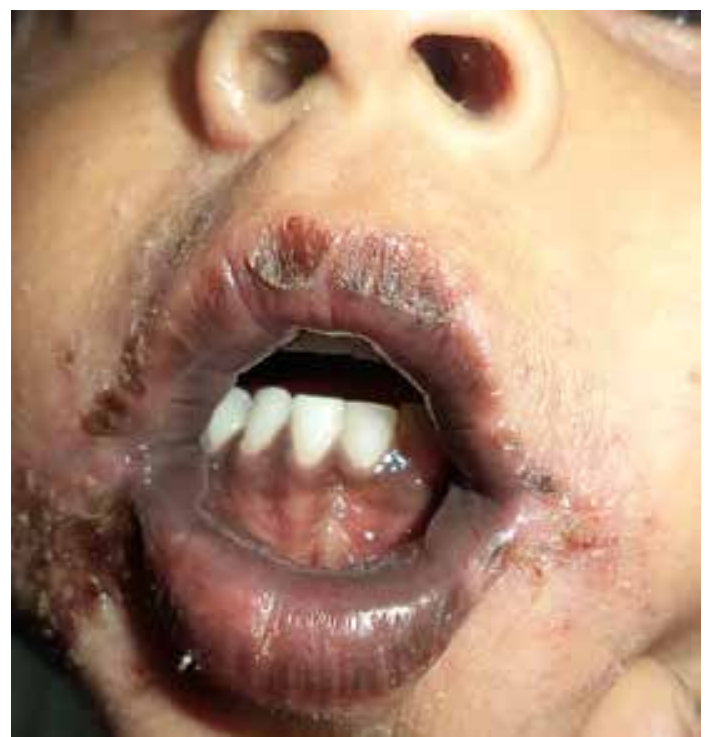

Figure 3. Crusted lesions around mouth with diffuse violaceous pigmentation over oral mucosa

Rycina 3. Strupy wokół ust oraz rozlane, fioletowe przebarwienia błony śluzowej jamy ustnej

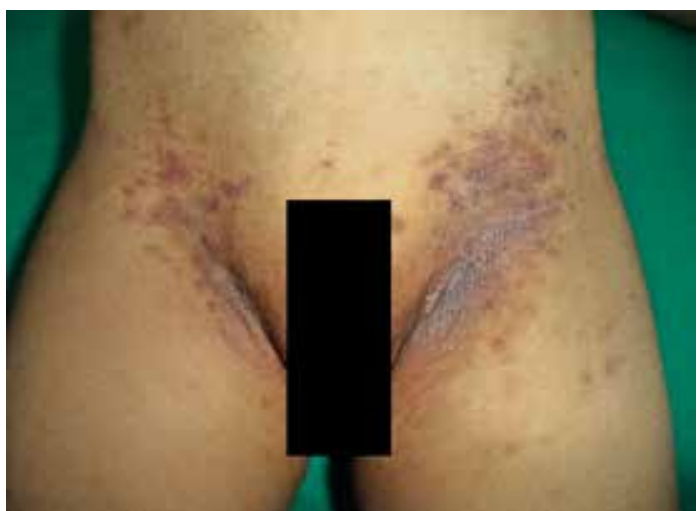

Figure 5. Eczematous lesions in groin with a background of pigmentation

Rycina 5. Zmiany wypryskowe w pachwinach z widocznymi przebarwieniami 
diffuse violaceous pigmentation and candidiasis (fig. 3). Teeth were normal. The rest of the cutaneous examination showed no abnormality. Both the ears showed a yellowish brown discharge. The musculoskeletal examination was normal. There was no abnormality on neurological, pulmonary, cardiovascular and abdominal examination.

The patient was found to have an absolute eosinophil count of 1200 cells $/ \mathrm{mm}^{3}$ and an extremely high serum IgE level of $4822 \mathrm{IU} / \mathrm{ml}$. The stool examination was positive for Giardia lamblia and culture from the ear discharge showed Staphylococcus aureus. Chest radiograph was within normal limits. Based on the clinical and laboratory features, a diagnosis of HIES was made. The patient obtained 33 points on the clinical scoring system devised by the National Institutes of Health, USA (NIH) for predicting autosomal dominant HIES, which is indeterminate (score $>40$ is suggestive of autosomal dominant HIES whereas score $20-40$ is indeterminate and $<20$ indicates that autosomal dominant HIES is unlikely) [2]. However, due to lack of facilities, genetic analysis was not done in our patient.

Hyper-IgE syndrome is a rare multisystem disease characterized by immune deficiency leading to skin and respiratory tract infections, eczema and high levels of IgE [3]. The classical disease form is autosomal dominant and occurs due to hypomorphic mutations in the signal transducer and activator of transcription 3 (STAT3) gene and consequent impairment of the lymphocytes Th17 pathway [4]. This form is associated with various skeletal and dental abnormalities, characteristic facies, and formation of pneumatoceles, apart from the above manifestations. An autosomal recessive form of HIES was reported in 2004 characterized by significantly increased levels of IgE and eosinophilia, propensity for viral infections, absence of skeletal and dentition abnormalities and recurrent pneumonias without formation of pneumatoceles [5]. These patients frequently have autoimmune cytopenias and central nervous system deficits [6]. The role of Tyk2 mutations in autosomal recessive HIES is proposed but contested by some authors [7].

The presence of consanguinity, family history in two siblings, absence of bony or teeth abnormalities, extremely high levels of IgE and eosinophils, absence of pneumatoceles on chest radiograph and presence of recurrent bacterial and viral infections and finally the clinical score of 33 in our patient are the features that point towards a probable diagnosis of autosomal recessive HIES. The presence of mucosal and flexural pigmentation is a feature that is unique to our case, adding more rarity to our case.
W badaniu przedmiotowym stwierdzono niedobór masy ciała $(76,9 \%)$ oraz prawidłowy wzrost $(87,7 \%)$ w stosunku do wieku. Na skórze gładkiej czoła, karku, okolicy zausznej, dołach pachowych i pachwinach widoczne były miodowożółte strupy z delikatnym złuszczaniem (ryc. 1, 2). Szczególnie nasilone strupy występowały wokół ust (ryc. 3). Obustronnie w dołach pachowych i pachwinach stwierdzono przebarwienia (ryc. 4, 5). Na błonie śluzowej jamy ustnej i policzków obserwowano rozlane, fioletowe przebarwienia oraz kandydozę (ryc. 3). Stan uzębienia był prawidłowy. $\mathrm{W}$ badaniu skóry nie wykazano innych nieprawidłowości. Stwierdzono również żółtobrązową wydzielinę z uszu. Badanie układu mięśniowo-szkieletowego nie ujawniło nieprawidłowości. Odchyleń od normy nie wykazano także w badaniu układu nerwowego, płuc, układu krążenia i jamy brzusznej.

Bezwzględna liczba eozynofilów u pacjentki wynosiła $1200 / \mathrm{mm}^{3}$. Stwierdzono znacznie podwyższone stężenie przeciwciał IgE w surowicy - $4822 \mathrm{IU} / \mathrm{ml}$. Badanie kału dało wynik dodatni w kierunku Giardia lamblia. W posiewie wydzieliny z uszu obecne były bakterie Staphylococcus aureus. Wynik badania RTG klatki piersiowej był w normie. Na podstawie obrazu klinicznego i wyników badań laboratoryjnych ustalono rozpoznanie HIES. Pacjentka uzyskała 33 pkt wg klinicznej oceny w skali opracowanej przez National Institutes of Health, USA (NIH), która umożliwia oszacowanie prawdopodobieństwa występowania autosomalnego dominującego HIES. Oznacza to wynik niepewny (wynik $>40$ sugeruje autosomalny dominujący HIES, podczas gdy wynik 20-40 oceniany jest jako nieokreślony, a < 20 wskazuje, że autosomalny dominujący HIES jest mało prawdopodobny) [2]. Ze względu na brak możliwości nie przeprowadzono analizy genetycznej.

Zespół hiper-IgE jest rzadką chorobą wieloukładową, którą cechuje niedobór odporności wywołujący zakażenia skóry i układu oddechowego, zmiany wypryskowe na skórze oraz duże stężenie przeciwciał IgE [3]. Postać klasyczna choroby jest dziedziczona w sposób autosomalny dominujący i wynika z hipomorficznych mutacji genu STAT3 (transduktora sygnału i aktywatora transkrypcji 3), a w efekcie upośledzenia szlaku limfocytów Th17 [4]. W przebiegu tej postaci choroby poza powyższymi objawami stwierdza się różne nieprawidłowości układu szkieletowego i uzębienia, charakterystyczne rysy twarzy oraz torbiele płucne (pneumatocele). Postać HIES o dziedziczeniu autosomalnym recesywnym opisano w 2004 r. Wśród jej cech wymieniono znacznie podwyższone stężenie przeciwciał IgE i eozynofilię, podatność na zakażenia wirusowe, brak nieprawidłowości w obrębie szkieletu i uzębienia oraz nawracające zapalenia płuc bez powstawania torbieli typu pneumatocele [5]. U chorych często stwierdza się cytopenie autoimmunologiczne oraz zaburzenia ośrod- 


\section{CONFLICT OF INTEREST}

The authors declare no conflict of interest. kowego układu nerwowego [6]. W autosomalnym recesywnym HIES wskazywano również na rolę mutacji Tyk2, choć pogląd ten jest kwestionowany przez niektórych autorów [7].

U pacjentki na prawdopodobne rozpoznanie autosomalnego recesywnego HIES wskazują: pokrewieństwo pomiędzy rodzicami, dodatni wywiad rodzinny (choroba u dwojga rodzeństwa), brak nieprawidłowości w obrębie układu kostnego i uzębienia, istotnie podwyższone stężenie IgE, zwiększona bezwzględna liczba eozynofilów, brak torbieli płucnych (pneumatocele) w RTG klatki piersiowej, nawracające zakażenia bakteryjne i wirusowe oraz wynik 33 pkt w skali oceny klinicznej. Unikatowa w opisanym przypadku jest obecność przebarwień obejmujących błony śluzowe i skórę na powierzchniach zgięciowych.

\section{KONFLIKT INTERESÓW}

Autorzy deklarują brak konfliktu interesów.

\section{References}

\section{Piśmiennictwo}

1. Muhammed K.: Hyper IgE syndrome: report of two cases with moderate elevation of IgE. Indian J Dermatol Venereol Leprol $2005,71,112-114$

2. Grimbacher B., Schäffer A.A., Holland S.M., Davis J., Gallin J.I., Malech H.L., et al.: Genetic linkage of hyper-IgE syndrome to chromosome 4. Am J Hum Genet 1999, 65, 735-744.

3. Arif T., Adil M., Amin S.S.: Autoimmune hypothyroidism in Jobs syndrome: an extremely rare finding. Indian J Paediatr Dermatol 2017, 18, 145-147.

4. Szczawinska-Poplonyk A., Kycler Z., Pietrucha B., Heropolitanska-Pliszka E., Breborowicz A., Gerreth K.: The hyperimmunoglobulin E syndrome - clinical manifestation diversity in primary immune deficiency. Orphanet J Rare Dis 2011, 6, 76.

5. Renner E.D., Puck J.M., Holland S.M., Schmitt M., Weiss M., Frosch M., et al.: Autosomal recessive hyperimmunoglobulin E syndrome: a distinct disease entity. J Pediatr 2004, 144, 93-99.

6. Freeman A.F., Holland S.M.: Clinical manifestations, etiology and pathogenesis of the hyper Ig E syndromes. Pediatr Res 2009, $65,32 \mathrm{R}-37 \mathrm{R}$.

7. Woellner C., Schäffer A.A., Puck J.M., Renner E.D., Knebel C., Holland S.M., et al.: The hyper IgE syndrome and mutations in Tyk2. Immunity 2007, 26, 535.

Received: 27.02.2017

Accepted: 17.06 .2017

Otrzymano: 27.02.2017 r

Zaakceptowano: $17.06 .2017 \mathrm{r}$.

How to cite this article

Arif T., Adil M., Amin S.S., Dorjay K.: An observation of autosomal recessive hyper-IgE syndrome: a rare case report. Dermatol Rev/Przegl Dermatol 2017, 104, 676-679. DOI: https://doi.org/10.5114/dr.2017.71840. 